\title{
Rancang Bangun E-Library pada SMAN 1 Pagerbarang Tegal
}

\author{
Yunita $^{[1]}$, Maruloh ${ }^{[2]}$, Alquraini Nur Ayatilah Saputri ${ }^{[3]}$ \\ STMIK Nusa Mandiri Jakarta ${ }^{[1],[2],}$ AMIK BSI Jakarta ${ }^{[3]}$ \\ Teknik Informatika ${ }^{[1]}$, Sistem Informasi ${ }^{[2]}$, Manajemen Informatika ${ }^{[3]}$ \\ yunita.yut@nusamandiri ${ }^{[1]}$, maruloh.mru@gmail.com ${ }^{[2]}$.kputry4@gmail.com ${ }^{[3]}$
}

\begin{abstract}
Abstraksi- Teknologi informasi merupakan salah satu hal penting pada era globalisasi saat ini. Perkembangan imu teknologi dan pengetahuan selalu memicu manusia untuk berkembang dan bersaing dalam pengusaan teknologi khususnya teknologi informasi dan komputer. Salah satunya internet, internet dapat memberikan kemudahan mencari informasi di segala aspek. Perkembangan ilmu teknologi berpengaruh pada dunia pendidikan. Banyak lembaga pendidikan yang memanfaatkan teknologi internet untuk memberikan informasi kepada masyarakat. Sistem infomasi perpustakaan merupakan suatu sistem yang memudahkan user untuk mencari informasi dengan menggunakan jaringan internet. Mempermudah dalam menyimpan data dan mengolah data dengan cepat dan tepat tanpa membutuhkan waktu lama dalam proses pengerjaannya. Melihat kenyataan diatas, penulis membuat program sistem informasi e-library yang ditunjukan pada "SMA $N$ Pagerbarang, Tegal". Bertujuan untuk mempermudah pelayanan perpustakaan dan mempermudah siswa mendapatkan buku referensi dan mata pelajaran. Siswa juga dipermudah untuk mencari informasi tentang artikel yang ada pada website $e$ library. Perancangan program e-library ini dibuat menggunakan Adobe Dreamweaver CS6, php dan mysql. Program ini dibuat untuk mempermudah siswa mendapatkan e-book tanpa harus datang ke perpustakaan. Dan mempermudah pegawai perpustakaan untuk mengolah data yang sudah ada. Program ini dibuat untuk memecahkan masalah yang ada seperti kendala waktu dan tempat. Dengan adanya program ini maka kegiatan akan lebih efektif dan efisien.
\end{abstract}

Kata kunci : Informasi, E-Library, Website.

\section{PENDAHULUAN}

Perpustakaan merupakan tempat mencari ilmu dan referensi buku untuk menambah ilmu pengetahuan. Pada setiap sekolah terdapat perpustakaan yang digunakan untuk kegiatan pembelajaran. Akan tetapi tidak semua sekolah memiliki perpustakaan dengan fasilitas online. Begitu juga dengan SMA N 1 PAGERBARANG terdapat sebuah perpustakaan yang masih berjalan secara manual. Seperti pendataan buku, daftar pengunjung, pendataan peminjaman dan pengembalian, serta keanggotan perpustakaan yang masih manual.

Namun seiring berjalannya waktu dan meningkatnya teknologi maka perpustakaan yang masih berjalan secara manual sudah tidak efisien lagi. Dengan adanya permasalahan tersebut diperlukan suatu alat yang memiliki kemampuan untuk menyimpan informasi dalam jumlah banyak, mengambil data secara acak dalam waktu yang cepat. Sebagai solusinya adalah dengan penggunaan teknologi komputer yaitu sebagai media bantu dalam pengolahan data berbasis online.

\section{LANDASAN TEORI}

\section{A. Definisi E-Library}

Konsep e-library adalah sebuah perpustakaan digital yang ada dalam website chickaholic dengan menyediakan link buku elektronik (e-book) yang dapat didownload pengunjung dengan gratis, buku yang telah didownload tersebut dapat / bebas disebarluaskan kembali dengan tidak mengubah materi yang ada dan menghilangkan sumber penulisnya ${ }^{[1]}$.

\section{B. Website}

menjelaskan bahwa "Website merupakan salah satu sumber daya internet yang berkembang pesat. Informasi web didistribusikan melalui hypertext, yang memungkinkan suatu teks pendek menjadi acuan untuk membuka dokumen lain ${ }^{[2]}$

\section{Web Server}

Server Web adalah server internet yang digunakan sebagai koneksi dan transfer data. Ketika anda browsing Internet, browser anda bertindak sebagai klien yang akan disambungkan kepada Server Web dan Server Web akan kembali menampilkan informasi dari satu situs ${ }^{[3]}$.

\section{MySQL}

MySQL (My Structure Query Leanguage) adalah salah satu Database Management System (DBMS) dari sekian banyak DBMS seperti Oracle, MS SQL, Postagre SQL dan lainnya MySQL berfungsi untuk mengolah database menggunakan bahasa $S Q L^{[4]}$.

\section{E. Struktur Navigasi}

Struktur navigasi adalah Susunan Menu atau hirarki dari suatu situs yang menggambarkan isi dari setiap halaman dan link atau navigasi tiap halaman pada suatu situs $w_{e} b^{[5]}$. 
F. Entity Relationship Diagram (ERD)

ERD merupakan Model Entity Relationship yang berisi komponen-komponen himpunan entitas dan himpunan relasi yang masing-masing dilengkapi dengan atribut-atribut yang merepresentasikan seluruh fakta dari dunia nyata yang kita tinjau, dapat digambarkan dengan sistematis dengan mengunakan Diagram Entity Relationship ${ }^{[6]}$.

\section{G. Logical Record Structure (LRS)}

memberikan batasan bahwa LRS adalah sebuah model sistem yang digambarkan dengan sebuah diagram-ER akan mengikuti pola atau aturan permodelan tertentu dalam kaitanya dengan konvensi ke $\operatorname{LRS}^{[7]}$

\section{H. Pengujian Web dengan Black-box testing}

Black-box testing dilakukan untuk mengetahui apakah fungsi-fungsi yang dibuat sudah berjalan dengan benar atau tidak. Black-Box Testing digunakan untuk mendemonstrasikan fungsi software yang dioperasikan, apakah input diterima dengan benar, dan output yang dihasilkan benar. ${ }^{[8]}$

\section{Model Pengembangan Perangkat Lunak}

Model Air Terjun (Waterfall) sering juga disebut model sekuensial linier (Sequential Linear) atau alur hidup klasik (Classic Life Cycle). Model air terjun menyediakan pendekatan alur hidup perangkat lunak secara sekuensial atau terurut dimulai dari analisis, desain, pengodean, pengujian dan tahap pendukung (support) ${ }^{[9] .}$

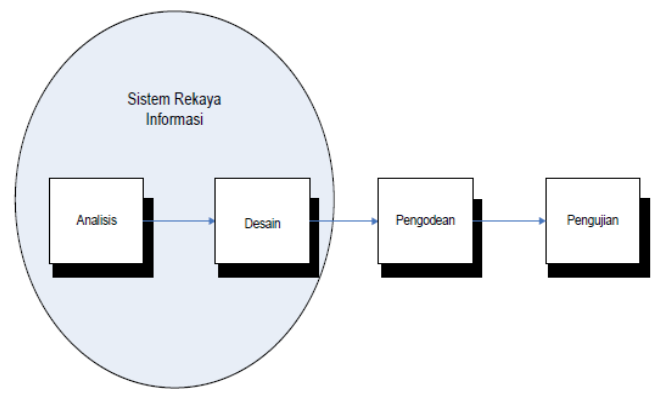

Sumber : Sukamto dan Shalahuddin (2013:29)

\section{Gambar 1. Ilustrasi Model Waterfall}

1. Analisa Kebutuhan Perangkat Lunak

Proses pengumpulan kebutuhan dilakukan secara intensif untuk menspesifikasikan kebutuhan perangkat lunak agar dapat dipahami perangkat lunak seperti apa yang dibutuhkan oleh user. Spesifikasi kebutuhan perangkat lunak pada tahap ini perlu untuk di dokumentasikan.

2. Desain

Desain perangkat lunak adalah proses multi langkah yang fokus pada desain pembuatan program perangkat lunak termasuk struktur data, arsitektur perangkat lunak, representasi antarmuka, dan prosedur pengodean. Tahap ini mentransisi kebutuhan perangkat lunak dari tahap analisis kebutuhan ke representasi desain agara dapat diimplementasikan menjadi program pada tahap selanjutnya. Desain perangkat lunak yang dihasilkan pada tahap ini juga perlu didokumentasikan.

3. Pembuatan Kode Program

Desain harus ditranslasikan ke dalam program perangkat lunak. Hasil dan tahap ini adalah program komputer sesuai dengan desain yang telah dibuat pada tahap desain.

4. Pengujian

Pengujian fokus pada perangkat lunak secara dan segi logik dan fungsional dan memastikan bahwa semua bagian sudah diuji. Hal ini dilakukan untuk meminimalisir kesalahan (error) dan memastikan keluaran yang dihasilkan sesuai dengan yang diinginkan.

5. Pendukung (Support) atau Pemeliharaan (maintenance) Tidak menutup kemungkinan sebuah perangkat lunak mengalami perubahan ketika sudah dikirimkan ke user. Perubahan bisa terjadi karena adanya kesalahan yang muncul dan tidak terdeteksi saat pengujian atau perangkat lunak harus beradaptasi dengan lingkungan yang baru. Tahap pendukung atau pemeliharaan dapat mengulangi proses pengembangan mulai dari analisis spesifikasi untuk perubahan perangkat lunak yang sudah ada, tapi tidak untuk membuat perangkat lunak yang baru.

\section{METODE PENELITIAN}

A. Metode Pengembangan Perangkat Lunak

Metode yang digunakan penulis dalam pengembangan perangkat lunak yaitu menggunakan metode Waterfall. Yang terbagi menjadi lima tahapan, yaitu:

1. Analisa Kebutuhan Perangkat Lunak

Perpustakaan SMA N 1 PAGERBARANG dalam melakukan pendataan buku dan keanggotaan masih secara manual, sehingga tidak bekerja secara efisien, dan penulis membuat sebuah rancangan program E-library sesuai dengan kebutuhan pengguna.

2. Desain

Penulis membuat rancangan desain program perangkat lunak termasuk struktur data, arsitektur perangkat lunak, representasi desain menggunakan Cascading Style Sheet (CSS) yang terdapat dalam software Adobe Dreamweaver CS6 agar dapat diimplementasikan menjadi sebuah program berbasis web.

3. Pembuatan Kode Program

Penulis membuat rancangan sistem informasi E-library dengan menggunakan Adobe Dreamweaver CS6, pada tahap perancangan basis data penulis menggunakan Entity Relational Database (ERD) sebagai alat untuk merancang relasi antar tabel dalam database untuk kemudian dikonversikan ke dalam bentuk Logical Record Structure (LRS) untuk membuat database dengan nama perpustakaan menggunakan web server Xampp 1.7.2 sesuai dengan analisa kebutuhan.

4. Pengujian Unit

Penulis melakukan pengujian unit dan sistem menggunakan Mozilla Firefox, pengujian dilakukan pada 
server lokal (localhost), dalam pengujian sistem E-library penulis menggunakan metode pengujian black box

5. Pendukung dan Pemeliharaan

Tahap pendukung atau pemelihara dapat mengembangkan mulai dari analisis spesifikasi untuk perubahan perangkat lunak yang sudah ada

B. Teknik Pengumpulan Data

1. Observasi

Suatu metode pengumpulan data yang menggunakan proses pengamatan langsung oleh penulis terhadap kegiatan perpustakaan SMA N 1 PAGERBARANG

2. Wawancara

Suatu metode pengumpuan data yang menggunakan proses tanya jawab langsung oleh penulis kepada petugas perpustakaan SMA N 1 PAGERBARANG

3. Studi Pustaka

Dalam pembuatan Tugas Akhir ini penulis menggunakan pengumpulan data dari buku - buku, internet dan sumber referensi lain yang berkaitan dengan tema yang penulis ambil untuk mendukung data yang telah didapat

\section{HASIL DAN PEMBAHASAN}

A. Analisa Kebutuhan Pengguna

1. Admin

a. Dapat melakukan login ke halaman admin.

b. Dapat menambah, mengedit, dan menghapus anggota

c. Dapat menambah, mengedit, dan menghapus ebook

d. Dapat membuat laporan pengunjung, laporan anggota, dan laporan e-book

e. Dapat menambah, mengedit, dan menghapus user

f. Dapat menghapus pesan masuk.

2. Anggota
a. Dapat melakukan login ke halaman user
b. Dapat mengisi buku pengunjung
c. Dapat mendownload e-book
d. Dapat mengirim pesan

3. Pengunjung

a. Dapat melihat halaman depan e-library

b. Dapat mendaftar sebagai user

c. Dapat mengirim pesan

B. Analisa Kebutuhan Perangkat Keras dan Lunak

1. Perangkat Keras

a. Server

1). CPU
a) Processor Intel ${ }^{\circledR}$ Core (TM) i3-3110M CPU @ 2,40Ghz.
b) RAM DDR 3,200 GB

2). Mouse

3). Keyboard

4). Monitor

5). Koneksi Internet b. Client

1). $\mathrm{CPU}$

a) Processor Intel ${ }^{\circledR}$ Core (TM) i3-3110M CPU @ 2,40Ghz.

b) RAM DDR 3,200 GB

2). Mouse

3). Keyboard

4). Monitor

5). Koneksi Internet

2. Perangkat Lunak

a. Server

1) Operating system microsoft windows 7 ultimate 32-bit

2) Web server Xampp 1.7.2

b. Client

1) Operating system microsoft windows 7 ultimate 32-bit

2) Web Browser Mozilla Firefox/Opera/Crome

C. Perancangan Perangkat Lunak

1. Rancangan Antar Muka

a. Rancangan antar muka Index

\begin{tabular}{|c|}
\hline HEADER \\
\hline LOGIN PESAN \\
\hline MENU BAR \\
ISI \\
\\
footer \\
\hline
\end{tabular}

Gambar 2. Rancangan antar muka Index

b. Rancangan antar muka Login

HOME

\section{LOGIN DISINI}

USERNAME

PASSWORD

\section{LOGIN RESET}

DAFTAR

Gambar 3. Rancangan antar muka Login 
c. Rancangan antar muka admin

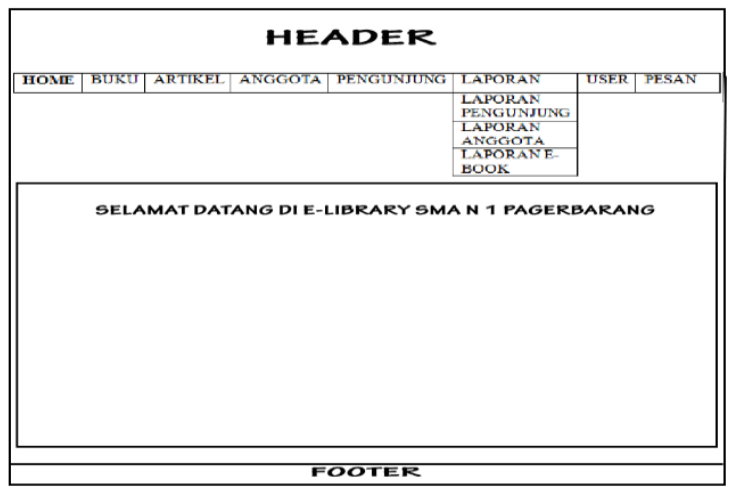

Gambar 4. Rancangan antar muka Admin

d. Rancangan antarmuka member

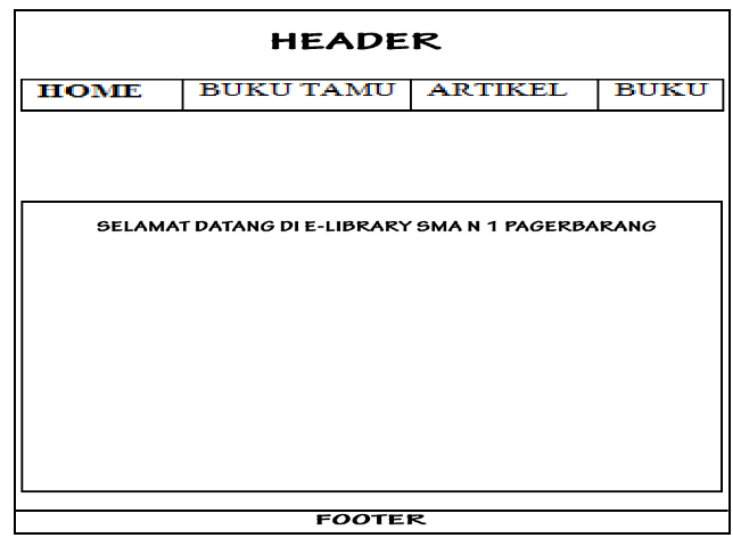

Gambar 5. Rancangan antar muka member

2. Rancangan Basis Data

a. Entity Relationship Diagram

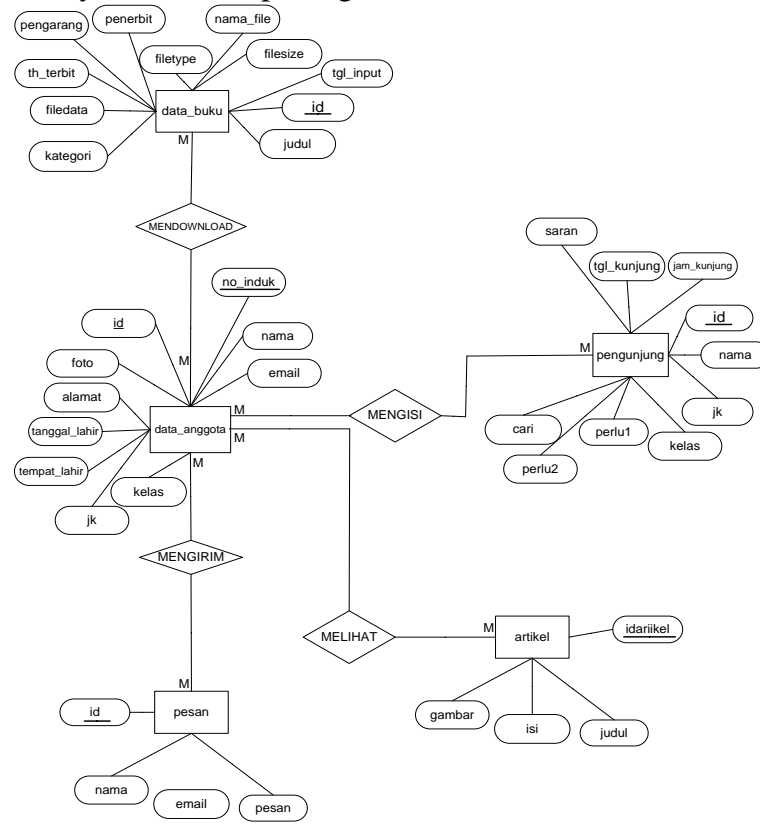

Gambar 6. Entity Relationship Diagram

3. Rancangan Struktur Navigasi

a. Struktur Navigasi Halaman Admin

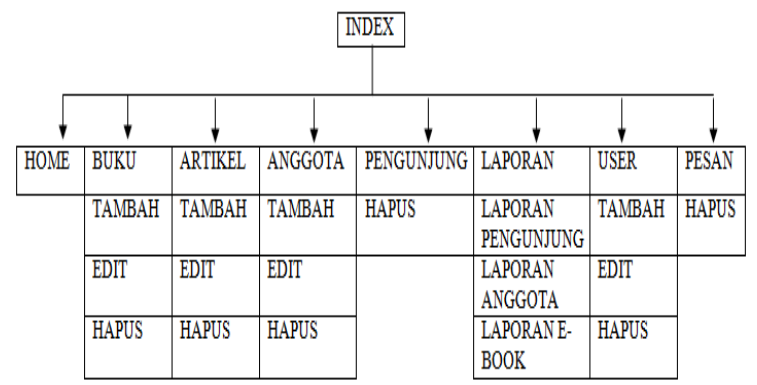

Gambar 7.Struktur Navigasi Halaman Admin

b. Struktur Navigasi Halaman User

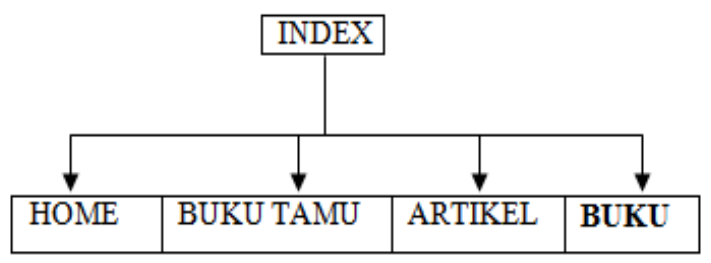

Gambar 8.Struktur Navigasi Halaman User

D. Implementasi dan Pengujian Unit

1. Implementasi Rancangan Antar Muka

a. Halaman Index

Halaman index merupakan halaman awal saat website dibuka. Tampilan Index dapat dilihat pada gambar 9.

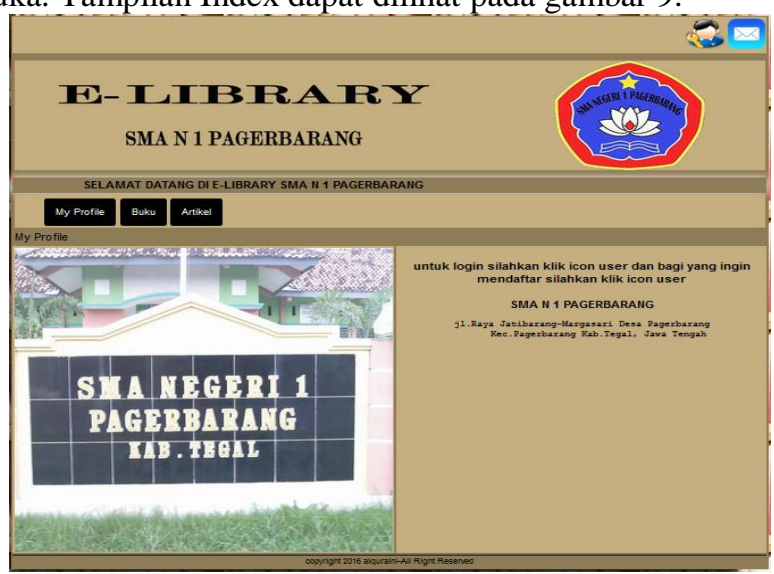

b. Halaman Login

Gambar 9.Halaman Index

Halaman login hanya dapat dibuka oleh anggota yang sudah terdaftar. Dengan memasukkan username dan password. Terdapat tombol Register untuk mendaftar sebagai anggota perpustakaan online. 


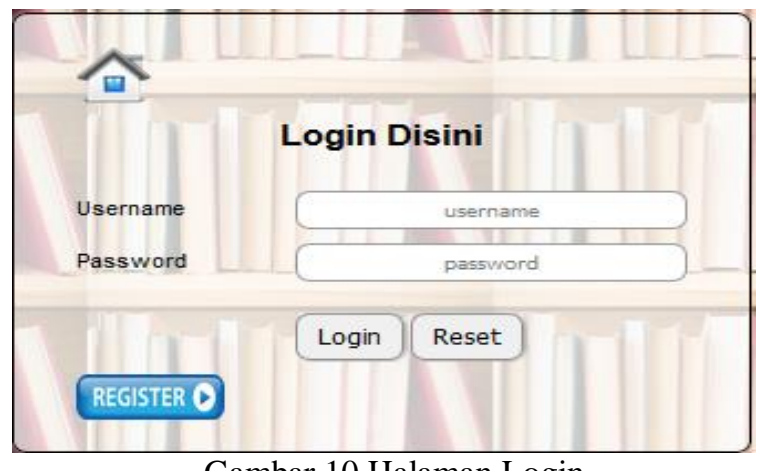

Gambar 10.Halaman Login

c. Halaman Admin

Halaman admin merupakan halaman awal saat login admin berhasil. Dalam halaman admin terdapat menumenu untuk mengatur buku, artikel, anggota, pengunjung, laporan, member,dan pesan.

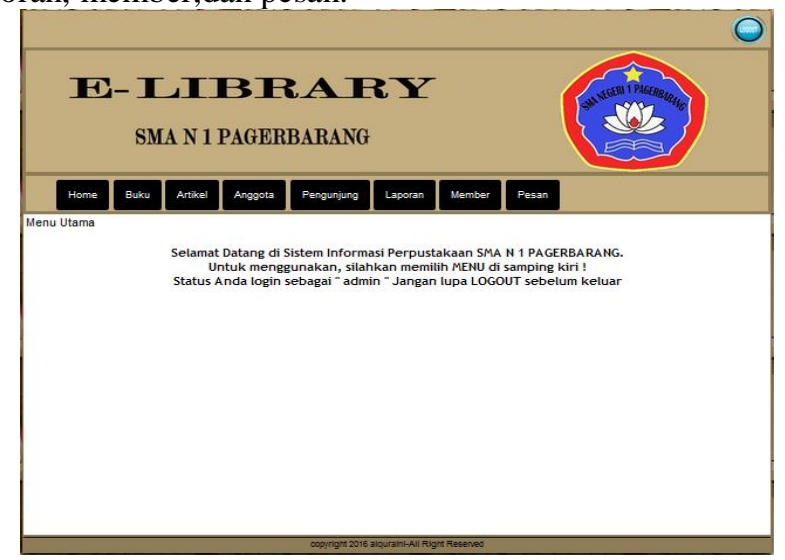

Gambar 10.Halaman Login

d. Halaman Member

Halaman member adalah halaman awal saat login member berhasil. Dalam halaman member terdapat menu buku tamu, artikel, dan buku yang dapat di download

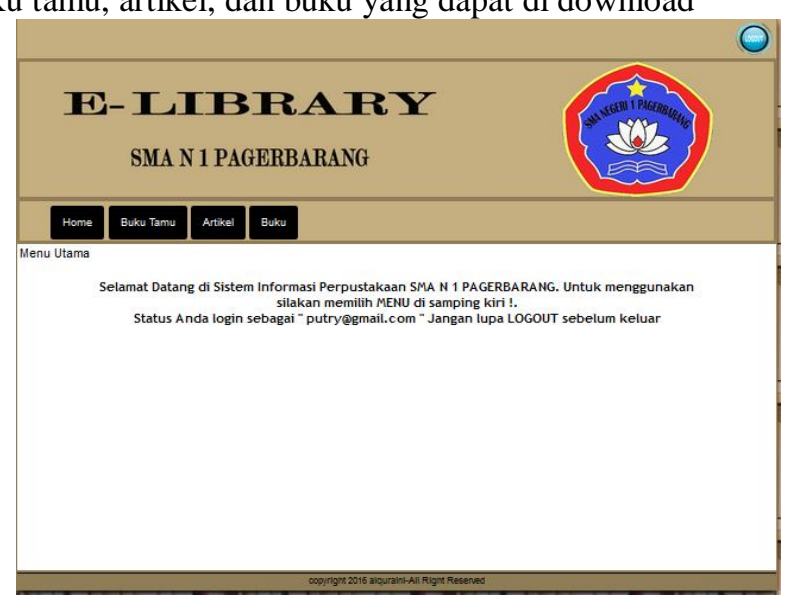

Gambar 10.Halaman Login
2. Pengujian Unit

a. Pengujian Unit Form Login Admin dan User

Tabel 1. Hasl Pengujian Black Box Form Login

\begin{tabular}{|c|c|c|c|c|}
\hline $\begin{array}{l}\text { Skenario } \\
\text { Pengujian }\end{array}$ & Test Case & $\begin{array}{l}\text { Hasil yang } \\
\text { diharapkan }\end{array}$ & $\begin{array}{c}\text { Hasil } \\
\text { Pengujia } \\
\mathbf{n}\end{array}$ & $\begin{array}{l}\text { Kesim } \\
\text { pulan }\end{array}$ \\
\hline $\begin{array}{l}\text { Username } \\
\text { dan } \\
\text { Password } \\
\text { tidak diisi } \\
\text { kemudian } \\
\text { klik tombol } \\
\text { login }\end{array}$ & $\begin{array}{l}\begin{array}{l}\text { Username } \\
\text { (kosong) }\end{array} \\
\text { Password } \\
\text { (kosong) }\end{array}$ & $\begin{array}{l}\text { Sistem akan } \\
\text { menolak } \\
\text { dan muncul } \\
\text { peringatan, } \\
\text { "Pengisian } \\
\text { form belum } \\
\text { benar" }\end{array}$ & $\begin{array}{l}\text { Sesuai } \\
\text { harapan }\end{array}$ & Valid \\
\hline $\begin{array}{l}\text { Username } \\
\text { diisi } \\
\text { sedangkan } \\
\text { Password } \\
\text { dikosongka } \\
\text { n kemudian } \\
\text { klik tombol } \\
\text { login } \\
\end{array}$ & $\begin{array}{l}\begin{array}{l}\text { Username } \\
\text { (admin) }\end{array} \\
\text { Password } \\
\text { (kosong) }\end{array}$ & $\begin{array}{l}\text { Sistem akan } \\
\text { menolak } \\
\text { dan muncul } \\
\text { peringatan, } \\
\text { "Pengisian } \\
\text { form belum } \\
\text { benar" }\end{array}$ & $\begin{array}{l}\text { Sesuai } \\
\text { harapan }\end{array}$ & Valid \\
\hline $\begin{array}{l}\text { Username } \\
\text { dikosongka } \\
\text { n } \\
\text { sedangkan } \\
\text { Password } \\
\text { diisi } \\
\text { kemudian } \\
\text { klik tombol } \\
\text { login }\end{array}$ & $\begin{array}{l}\begin{array}{l}\text { Username } \\
\text { (kosong) }\end{array} \\
\text { Password } \\
\text { (admin) }\end{array}$ & $\begin{array}{l}\text { Sistem akan } \\
\text { menolak } \\
\text { dan muncul } \\
\text { peringatan, } \\
\text { "Pengisian } \\
\text { form belum } \\
\text { benar" }\end{array}$ & $\begin{array}{l}\text { Sesuai } \\
\text { harapan }\end{array}$ & Valid \\
\hline $\begin{array}{l}\text { Salah } \\
\text { mengetikan } \\
\text { pada } \\
\text { Username } \\
\text { dan } \\
\text { Password } \\
\text { kemudian } \\
\text { klik tombol } \\
\text { login }\end{array}$ & $\begin{array}{l}\text { Username } \\
\text { admin } \\
\text { (benar) } \\
\text { Password } \\
\text { putry(sala } \\
\text { h) }\end{array}$ & $\begin{array}{l}\text { Sistem akan } \\
\text { menolak } \\
\text { dan muncul } \\
\text { peringatan, } \\
\text { "Anda } \\
\text { Gagal } \\
\text { Login" }\end{array}$ & $\begin{array}{l}\text { Sesuai } \\
\text { harapan }\end{array}$ & Valid \\
\hline $\begin{array}{l}\text { Benar } \\
\text { mengetikan } \\
\text { pada } \\
\text { Username } \\
\text { dan } \\
\text { Password } \\
\text { kemudian } \\
\text { klik tombol } \\
\text { login }\end{array}$ & $\begin{array}{l}\text { Username } \\
\text { admin(ben } \\
\text { ar) } \\
\text { Password } \\
\text { admin(ben } \\
\text { ar) }\end{array}$ & $\begin{array}{l}\text { Sistem } \\
\text { menerima } \\
\text { kemudian } \\
\text { menampilka } \\
\text { n, "Anda } \\
\text { Berhasil } \\
\text { Login" } \\
\text { Kemudian } \\
\text { menampilka } \\
\text { n menu } \\
\text { utama }\end{array}$ & $\begin{array}{l}\text { Sesuai } \\
\text { harapan }\end{array}$ & Valid \\
\hline
\end{tabular}

b. Pengjian Unit Form Input Data Anggota

Tabel 2. Hasl Pengujian Black Box Form input data anggota

\begin{tabular}{|l|l|l|l|l|}
\hline $\begin{array}{c}\text { Skenario } \\
\text { Pengujian }\end{array}$ & Test Case & $\begin{array}{c}\text { Hasil yang } \\
\text { diharapkan }\end{array}$ & $\begin{array}{c}\text { Hasil } \\
\text { Pengujia } \\
\text { n }\end{array}$ & $\begin{array}{c}\text { Kesim } \\
\text { pulan }\end{array}$ \\
\hline $\begin{array}{l}\text { Salah satu } \\
\text { field tidak } \\
\text { terisi }\end{array}$ & $\begin{array}{l}\text { Nama } \\
\text { (kosong) }\end{array}$ & $\begin{array}{l}\text { Sistem } \\
\text { menolak } \\
\text { kemail } \\
\text { maka akan } \\
\text { klik input }\end{array}$ & $\begin{array}{l}\text { Sesuai } \\
\text { Harapan }\end{array}$ & Valid \\
& $\begin{array}{l}\text { JK } \\
\text { (kosong) }\end{array}$ & $\begin{array}{l}\text { muncul } \\
\text { peringatan, } \\
\text { "Pengisian }\end{array}$ & & \\
\hline
\end{tabular}




\begin{tabular}{|c|c|c|c|c|}
\hline & 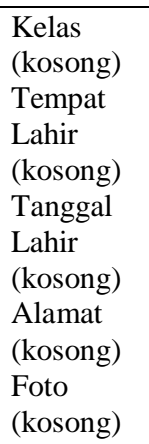 & $\begin{array}{l}\text { Form Belum } \\
\text { Benar Harap } \\
\text { Ulangi } \\
\text { Lagi" }\end{array}$ & & \\
\hline $\begin{array}{l}\text { Mengisi } \\
\text { dengan } \\
\text { benar } \\
\text { semua field } \\
\text { Kemudian } \\
\text { klik input }\end{array}$ & $\begin{array}{l}\begin{array}{l}\text { Nama } \\
\text { (terisi) }\end{array} \\
\text { Email } \\
\text { (terisi) } \\
\text { JK (terisi) } \\
\text { Kelas } \\
\text { (terisi) } \\
\text { Tempat } \\
\text { Lahir } \\
\text { (terisi) } \\
\text { Tanggal } \\
\text { Lahir } \\
\text { (terisi) } \\
\text { Alamat } \\
\text { (terisi) } \\
\text { Foto } \\
\text { (terisi) }\end{array}$ & $\begin{array}{l}\text { Sistem } \\
\text { menerima } \\
\text { kemudian } \\
\text { muncul, } \\
\text { "Data } \\
\text { Anggota } \\
\text { Telah } \\
\text { Ditambahka } \\
\text { n" dan } \\
\text { diteruskan } \\
\text { ke halaman } \\
\text { berikutnya }\end{array}$ & $\begin{array}{l}\text { Sesuai } \\
\text { Harapan }\end{array}$ & Valid \\
\hline
\end{tabular}

\section{PENUTUP}

A. Kesimpulan

Berdasarkan uraian yang telah dibahas maka penulis menarik kesimpuan sebagai berikut

- E-library yang dibuat Memudahkan siswa dalam proses pencarian buku, mendownload E-book dan melihat artikel

- Dengan adanya website ini memudahkan siswa mencari lebih banyak informasi dan wawasan

- Dengan adanya E-library SMA N 1 Pagerbarang ini memudahkan petugas untuk melakukan pendataan buku dan pendataan anggota

- E-library yang dibuat dapat menghemat waktu, tenaga, dan biaya

\section{B. Saran}

penulis dapat memberikan beberapa saran sebagai bahan pertimbangan guna meningkatkan kinerja program di masa mendatang, antara lain:

- Petugas lebih baik mengganti password secara berkala untuk kepentingan keamaanan data perpustakaan SMA N 1 Pagerbarang.

- Untuk kedepannya sebaiknya program E-library ini memiliki desain yang lebih menarik lagi serta memiliki fitur yang lebih banyak lagi

- Sebaiknya petugas perpustakaan melakukan backup dan maintenance secara rutin demi kepentingan keamanan dan mencegah data hilang apabila web server yang digunakan sedang down atau rusak

- Melakukan pelatihan bagi pengguna website e-library dan petugas perpustakaan

\section{DAFTAR PUSTAKA}

[1] Anonim. 2009. Panduan Pengelolaan Perpustakaan Sekolah Dasar. Jakarta: Depdiknas.

[2] Sutarman. 2007. Membangun Aplikasi Web Dengan PHP dan MySQL. Yogyakarta : GRAHA ILMU.

[3] Saputra dan Ramadani. 2010. Simple Step Programming with CCS: Mengungkap rahasia pembuatan aplikasi sistem informasi tercepat. Jakarta: PT Elex Media Komputindo.

[4] Anhar. 2010. Panduan Menguasai PHP \& MySQL Secara Otodidak.Jakarta:MediaKita.

[5] Hakim dan Lukmanul. 2009. Jalan Pintas Menjadi Master PHP.Yogyakarta:Lokomedia.

[6] Fathansyah. 2007. Basis Data. Bandung : Informatika.

[7] Hasugian dan Ahmad Nur Shidiq. 2012. Rancang Bangun Sistem Informasi Industri Kreatif Bidang Penyewaan Sarana Olahraga. in Seminar Nasional Teknologi Informasi \& Komunikasi Terapan (Semantik): Semarang .

[8] Hamdani Nindyan P dan Yuli Astuti. 2017. "Sistem Informasi Manajemen Distribusi Gas 3kg Berbasis Web Dan Android Yang Terintegrasi (Studi Kasus : Pt. Tritra Perkasa Boyolali)". Jurnal Maklumatika.

[9] Sukamto, Rosa Ariani dan Muhammad Salahudin. 2013. Rekayasa Perangkat Lunak Terstruktur Dan Berorientasi Objek. Bandung: Informatik 